\title{
主成分分析と規準バリマックス回転を統合した衛星画像の色合成
}

\section{Color Composite of Satellite Remotely Sensed Image Integrating Principal Component Analysis and Normal Varimax Rotation}

\author{
清 水英範・表 明榮・四童子 隆 \\ Eihan SHIMIZU*, Myoung Young PIOR**, Takashi SHIDOUJ *
}

\begin{abstract}
Principal component analysis (PCA) is a multivariate statistical technique to summarize most of the variation in a observed multivariate system in fewer variables. It has been expected to be an useful technique to visualize the multiband remote sensing data. It is because the RGB color composite image using the summarized three principal components is expected to reflect as much information as possible of the original multivariate remote sensing data. It is known, however, that the actual color composite image employing PCA is not necessarily understandable one because the principal components are not distinctly correspondent to the electromagnetic wavelength, i. e. color, and consequently the relationship between the represented color and land cover becomes vague. This paper proposes a new type of the color composite technique by integrating PCA and the Normal Varimax Rotation (NVR). The NVR is employed to make more distinct the relationship between each principal component and the electromagnetic wavelength by rotating the three dimensional space constituted by the first to third principal components. Since the NVR gives the orthogonal rotation, the three components after rotation represent the whole information of the original three principal components. This paper also presents the practical comparisons among the color composite images which are constructed by the conventional false color composite, the ordinary PCA, and the proposed NVR integrated PCA technique.
\end{abstract}

\section{1.はじめに}

リモートセンシングデータのマルチバンド化が進む 中, 多バンドのデー夕をいかに有効に利用してリモー トセンシングデー夕を視覚化 (画像化) するかは, こ れまで以上に重要な問題になってきた。この問題に対 応するための一つの方法として主成分分析の適用が提 案されている1 3)。これは主成分分析によって多バンド の情報を 3 次元情報に次元縮小し, これらの各々に RGB 割り当てることによりカラー合成を行う方法 である。しかし，従来の主成分分析による画像合成で

* 東京大学大学院工学系研究科社会基盤工学専攻

Department of Civil Engineering University of Tokyo 113 文京区本郷7-3-1

\section{**運輸政策研究所}

Institute for Transport Policy Studies

105 港区虎ノ門3-18-19

「写真測量とリモートセンシング」VOL. 36, NO. 5， 1997
は，電磁波の波長带域との直接的な関連がない 3 次元 量である第一から第三主成分に，適当に RGB を割り 当てて画像合成を行っているため，主成分分析による 画像は, 土地被覆と色との対応が奇異であり, 色によっ て土地被覆の解釈ができないという判読上の大きなマ イナス面をもつ。

本研究は以上の背景のもと, 主成分分析画像の長所 を保持したままで欠点を改善することを目標とし，主 成分分析によって得られる各主成分に規準バリマック 又回転を施す視覚化手法を提案するものである。具体 的には，規準バリマックス回転によって各主成分（因 子）と波長帯域との関連を明示し，それを考慮した上 でRGB 合成を行う。これにより, 得られた画像は主成 分分析画像と同様に全バンドの情報を考虑し，かつ判 読しやすいものとなることが期待されるのである。 


\section{2. 従来の色合成手法 (フォールスカラー合 成)}

現在，リモートセンシングデータの視覚化に際して はフォールスカラー合成と呼ばれる手法が広く利用さ れている。この方法は, 多くのバンドの中から 3 つの バンドを選び，それぞれに赤，緑，青 $(\mathrm{R} \cdot \mathrm{G} \cdot \mathrm{B})$ を 割り当てることで画像を作成するものである。この手 法では，電磁波の波長带域と色との関係，あるいは植 生は近赤外線の反射率が高いといった地上物のスペク トル特性を踏まえた RGBの割り当てが可能であり， 人間が判読しやすい画像が得られるという利点がある 反面，より多くのバンドがあるにもかかわらず色の割 り当てに選択された 3 バンド以外のバンド情報が画像 の表示に反映されないという問題点を持つ。その結果 として, RGBの割り当ての仕方の異なるいくつかの フォールスカラー合成画像を作成し，それらを見比べ ながらの判読作業を強いられる場合もある。一方，主 成分分析画像は全バンドの情報を一枚の画像に集約で きるという強力な利点があるが，各主成分と波長带と の対応が明確でないために RGB をどのように割り当 てるべきかに関して指針がなく，また，そのために得 られた画像の色と土地被覆の関係が意味解釈しにくい ものとなるという重大な欠点を抱えている。

本研究の問題意識は, この主成分分析画像の利点は 確保した上で欠点を改善できないかというところにあ ク，そのための手法を提案する。そして提案した手法 による画像と従来のフォールスカラー合成画像との比 較を通して，その有効性を考察する。

本研究では，比較対象とするフォールスカラー合成 の方法として,トゥルーカラー合成, ナチュラルカラー 合成を用いた。なお，色合成手法の名称については文 献等で統一されていない。本研究では以下に述べるよ うに定義しておく。

トゥルーカラー合成：我々の目に見える可視領域の 3 バンドを用い，それぞれのバンドにもっとも近い色 を割り当てる方法である。この方法による画像は我及 が目で見るものにもっとも近いものとなる。

ナチュラルカラー合成：近赤外領域のバンドに緑を 割り当てて合成される。これは植物に含まれるクロロ フィルが近赤外線を強く反射するという性質を利用し
ている。すなわち，植物の存在するところが緑色にな るため, 人間による判読がしやすいという特徵をもつ。

\section{3 . 主成分分析とバリマックス回転}

\section{(1) 主成分分析 ${ }^{4)}$}

主成分分析とは，互いに相関のある多種類の変数の 情報を，互いに無相関な少数個の総合特性值(主成分) に要約する方法である。

今, $p$ 個の変数 $x_{1}, x_{2}, \cdots, x_{p}$ が存在するとする。この とき, 全ての変数の情報を考慮した $m$ 個の総合特性值

$\left(\begin{array}{c}f_{1} \\ f_{2} \\ \vdots \\ f_{m}\end{array}\right)=\left(\begin{array}{cccc}w_{11} & w_{12} & \cdots & w_{1 p} \\ w_{21} & w_{22} & \cdots & w_{2 p} \\ \vdots & \vdots & & \vdots \\ w_{m 1} & w_{m 2} & \cdots & w_{m p}\end{array}\right)\left(\begin{array}{c}x_{1} \\ x_{2} \\ \vdots \\ x_{p}\end{array}\right)$

を考え，これら $f_{1}, f_{2}, \cdots, f_{m}$ を順に第一，第二， $\cdots$ 第 $m$ 主成分とする。

ここで, $m$ 個の主成分を求める係数である因子負荷 量

$\boldsymbol{w}_{i}=\left(w_{i 1}, w_{i 2}, \cdots, w_{i p}\right)^{t}$

は，もとの変数 $x_{1}, x_{2}, \cdots, x_{p}$ の分散共分散行列 $\boldsymbol{C}_{x x}$ (ま たは $\boldsymbol{C}_{x x}$ を基準化した後の相関行列 $\boldsymbol{R}_{x x}$ ) の固有値を 大きい方から順に $m$ 個 $\left(\lambda_{1} \geq \lambda_{2} \geq \cdots \geq \lambda_{m}>0\right)$ とった時 の $i$ 番目の固有值 $\lambda_{i}$ に対応する正規固有べクトル, す なわち

$$
C_{x x} \boldsymbol{w}_{i}=\lambda_{i} \boldsymbol{w}_{i}
$$

$\mathcal{w}_{i 1}^{2}+w_{i 2}^{2}+\cdots+w_{i p}^{2}=\sum_{j=1}^{p} w_{i j}^{2}=1$

\section{によって与えられる。}

また, 第 $i$ 主成分 $f_{i}$ の分散は分散共分散行列 $\boldsymbol{C}_{x x}$ の $i$ 番目の固有值 $\lambda_{i}$ に一致し，このとき，異なる主成分 は互いに直交し， $f_{m}$ の分散は $f_{1}, f_{2}, \cdots, f_{m-1}$ の全てと 無相関な 1 次式のなかで最大となる。

この主成分分析を多バンドのリモートセンシング デー夕に適用し，第三主成分までを採用して RGB 合 成を行うことで，より多くの情報を含む画像を作成す ることができる。本研究では主成分分析の利用に際し ては, 各バンドのデー夕を平均 0 , 分散 1 に基準化し, 相関行列を始点とする方法を用いた。 


\section{（2）規準バリマックス回転45)}

主成分分析によって抽出された複数の主成分は, 相 互に無相関であるが，もとの変数とは互いに相関を有 する。各主成分の因子負荷量が, 各主成分ともとの変 数の相関係数に一致するため, この因子負荷量に基づ いて各主成分が意味する内容を考察するということが 行われる。しかし実際には, ある主成分はどの変数と も相関が大きく，また，ある主成分はどの変数とも相 関が小さいといった結果が生じ，各主成分が表現する 具体について, 解釈が困難であることも多い。そこで, 主成分軸を適当に回転させ，各主成分が比較的少数の ある変数群との相関のみが大きくなるようにし, 解釈 をしやすくするという方法が提案されている。これを 主成分軸の回転と呼ぶ。原理的には因子分析において しばしば用いられる因子軸の回転と全く同じである。 抽出した第 $m$ 主成分までに主成分軸の回転を施すこ とで，含まれる情報量の和(分散の和)を保ったままで 各主成分の解釈が可能となる。本研究では, 色空間内 での距離を保つという制約条件を考えるため, 直交回 転の一つである規準バリマックス法を用いる。

いま, 式（1）のように抽出された $m$ 個の主成分の, 回転後の因子負荷量を

$$
\boldsymbol{B}=\left(\begin{array}{cccc}
b_{11} & b_{12} & \cdots & b_{1 m} \\
b_{21} & b_{22} & \cdots & b_{2 m} \\
\vdots & \vdots & & \vdots \\
b_{p 1} & b_{p 2} & \cdots & b_{p m}
\end{array}\right)
$$

とする。このとき回転は, 各主成分がなるべく異なる 特定の変数と大きな正あるいは負の相関を持つように なされる。すなわち, 行列 $\boldsymbol{B}$ の各列は 1 あるいはー 1 に近い負荷量とゼロに近いもので構成されている必要 がある。バリマックス法では，この定性的な最適化基 準を,「因子負荷量の 2 乗值についての列内の分散の和 を最大化する」という規準で置き換える。このとき， 正規直交変換によって不変な共通度

$h_{i}=\sum_{j=1}^{m} b_{i j}^{2} \quad(i=1, \cdots, p)$

の小さい主成分の因子負荷量は, 回転後も小さくなっ てしまうという問題を解決するために, 規準バリマッ クス法では因子負荷量の第 $i$ 行を共通度 $h_{1}$ で除し, $q_{i j}^{2}=\left(b_{i j} / h_{i}\right)^{2}$ について列ごとの偏差平方和の総和

$$
\begin{aligned}
Q= & \sum_{j=1}^{m} \sum_{i=1}^{p}\left(q_{i j}^{2}-\bar{q}_{j}\right)^{2} \\
& \left(\text { ただし } \quad \bar{q}_{j}=\sum_{i=1}^{p} q_{i j}^{2} / p\right)
\end{aligned}
$$

を最大にするように回転を行う。

式 ( 7 )の最適化問題は多少複雑な非線形最適化問題 となり直接解くのは困難であるため, 一般には以下の ような解法が用いられる。まず $m$ 個の主成分について 任意の 2 主成分を取り上げ，その 2 主成分の張る平面 内で $Q$ を最大にするように回転を行う。平面内の直交 回転は, 回転の角度を $\theta$ とすれば,

直交行列 $\left(\begin{array}{cc}\cos \theta & \sin \theta \\ -\sin \theta & \cos \theta\end{array}\right)$

によって表わされ, 第 $k$ 主成分と第 $l$ 主成分を取り上 げた場合に変化を受けるのは行列 $\boldsymbol{B}$ の第 $k$ 列と第 $l$ 列だけである。その回転による $Q$ の変化量は $\theta$ の関 数として表わされるので，Qが最も増大するように $\theta$ を定めればよい。

角度 $\theta$ の範囲を $-\frac{\pi}{4} \leq \theta \leq \frac{\pi}{4}$ とすると $\theta$ は次式で 求まる。

$\theta=\frac{1}{4} \tan ^{-1}-\frac{\delta-2 \alpha \beta / p}{\gamma-\left(\alpha^{2}-\beta^{2}\right) / p}$

ここで,

$\alpha=\sum_{i=1}^{p}\left(q_{i k}^{2}-q_{i l}^{2}\right), \quad \quad \beta=2 \sum_{i=1}^{p} q_{i k} q_{i l}$,

$\gamma=\sum_{i=1}^{p}\left\{\left(q_{i k}^{2}-q_{i l}^{2}\right)^{2}-4 q_{i k}^{2} q_{i l}^{2}\right\}, \quad \delta=4 \sum_{i=1}^{p} q_{i k} q_{i l}\left(q_{i k}^{2}-q_{i l}^{2}\right)$

である。この回転を $m$ 個の主成分から選んだ $m(m$ $-1) / 2$ 通りの 2 主成分の組み合わせについて順に行 い,それを一巡として $Q$ が最大值に収束するまで繰り 返す。

\section{4，適用実験}

\section{（1）使用データ}

実験に使用したデータはタイ・バンコク周辺の LANDSAT・TM データ(1987年12月撮影)であり，熱 バンドを除く 6 バンドを対象にした。地上分解能は約 $30 \mathrm{~m}$, ピクセル, ライン数は共に 480 である。

\section{（2）主成分分析の適用}

テストデー夕に主成分分析を適用しな結果，得られ た主成分の寄与率等は表 1 のようになった。 
表 1 主成分分析の結果

\begin{tabular}{|c|c|r|c|}
\hline 主成分 & 固有值 & 寄与率 & 累積寄与率 \\
\hline 1 & 4.2031 & $70.1 \%$ & $70.1 \%$ \\
2 & 1.3802 & $23.0 \%$ & $93.1 \%$ \\
3 & 0.2700 & $4.5 \%$ & $97.6 \%$ \\
\hline 4 & 0.0954 & $1.6 \%$ & $99.2 \%$ \\
5 & 0.0316 & $0.5 \%$ & $99.7 \%$ \\
6 & 0.0196 & $0.3 \%$ & $100.0 \%$ \\
\hline
\end{tabular}

結果の累積寄与率に注目すると, 第一から第三主成 分までで全体の情報の $97 \%$ 以上の分散を説明してお ク，元の多バンドの情報を，情報の損失を $2 \%$ 程度に 抑之て 3 次元情報に次元縮小できたことがわかる。こ のことによって，第一から第三主成分までを用いて $\mathrm{RGB}$ 合成した画像は, 従来のフォールスカラ一画像に 比べ，少なくとも物理的には多くの情報を含むことに なる。

\section{（3）主成分分析画像の作成}

第一から第三主成分を用いて作成した画像が図 1 で ある。この画像は第一主成分に赤，第二主成分に緑， 第三主成分に青を割り当てて合成している。この割り 当てについては必ずしも一意なものではなく，色と主 成分の全ての組み合わせ（6通り）について検討し， 著者が最も好ましいと判断したものが図1である。図 2 にトゥルーカラー画像, 図 3 に近赤外領域に緑を割 り当てたナチュラルカラー画像を示す。水域と陸地の 境界や市街化地域の連続性に注目してこれらを比較す ると, 土地被覆の差異の識別性という点では, トゥルー
カラー画像よりもナチュラルカラー画像の方が, そし てナチュラルカラー画像よりも主成分分析画像の方が 優れているよjに思える。

一方，表 2 (a)を見ると，第一主成分 $(\mathrm{F} 1)$ はどの 波長带とも相関が大きく(因子負荷量が大きく), 第三 主成分（F3）は逆にどの波長帯とも相関が小さいこと が分かる。すなわち, 各主成分は人間に見える色（可 視光の各波長带）との対応, あるいは土地被覆との対 応(近赤外線との相関が大きければ植生といった对応) という点において, 意味解釈が困難な 3 次元量である といえる。このため, RGB 合成に際しての色の割り当 てについては何ら指針となるべきものがなく, このこ とによって主成分分析画像は色彩と土地被覆の対応が 奇異なものとなり, また, 得られる画像は単に土地被 覆の差異を異なる色で表示するだけのものとなってい る。つまり, 主成分分析画像を見るだけでは, 土地勘 の乏しい判読者には土地被覆の分布を把握することは 困難である。

\section{（4）規準バリマックス回転の適用}

主成分分析画像が以上のような欠点をもつのに対 し, フォールスカラー画像は含む情報量は少ないもの の, 表示される色と土地被覆との対応が分かりやすい という点で優れた面を持っている。このフォールスカ ラ一合成の利点は，物体の分光特性を考慮した色の割 ク当てが可能であることに起因している。

以上のことから，主成分分析画像では抽出される主 成分因子と波長带との関連が不明確であることが, 色 彩と土地被覆の対応が奇異なものとなる原因であると

\section{表 2 回転の前後の因子負荷量}

\begin{tabular}{|c|c|c|c|c|c|c|c|}
\hline \multirow[b]{2}{*}{ バント } & \multirow[b]{2}{*}{ ゙゙（波長带域） } & \multicolumn{3}{|c|}{$\begin{array}{l}\text { (a)回転前の因子負荷量 } \\
\text { (各主成分の因子負荷量) }\end{array}$} & \multicolumn{3}{|c|}{ (b)回転後の因子負荷量 } \\
\hline & & $\mathrm{F} 1$ & $\mathrm{~F} 2$ & F3 & $\mathrm{VF} 1$ & $\mathrm{VF} 2$ & VF3 \\
\hline 1 & (可視) & .790 & -.0 .57 & -.011 & .935 & .252 & -.109 \\
\hline 2 & (可視) & .893 & -.386 & .186 & .951 & .212 & .177 \\
\hline 3 & （可視） & .938 & -.247 & .107 & .879 & .342 & .250 \\
\hline 4 & （近赤外） & .561 & .760 & .312 & .036 & .300 & .948 \\
\hline 5 & (短波長赤外) & .860 & .470 & -.166 & .310 & .742 & .585 \\
\hline 7 & (短波長赤外) & .920 & .213 & .315 & .473 & 809 & .338 \\
\hline & 説明量 & 4.20 & 1.38 & .27 & 2.87 & 1.52 & 1.46 \\
\hline & 寄与率 & $70.1 \%$ & $23.0 \%$ & $4.5 \%$ & $47.9 \%$ & $25.3 \%$ & $24.4 \%$ \\
\hline & 意味解釈 & & 解釈困難 & & 可視 & 短波長 & 近赤外 \\
\hline
\end{tabular}




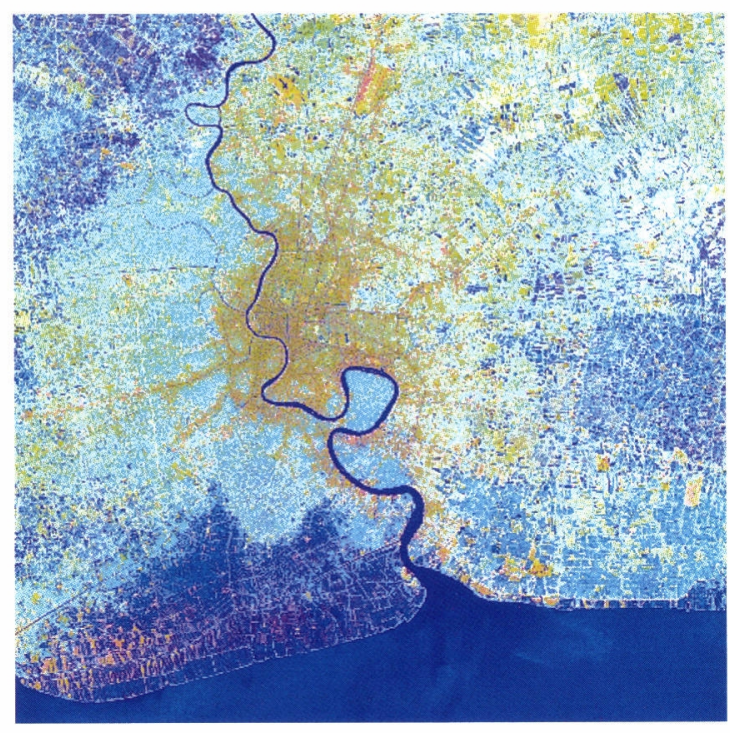

図 1 主成分分析画像

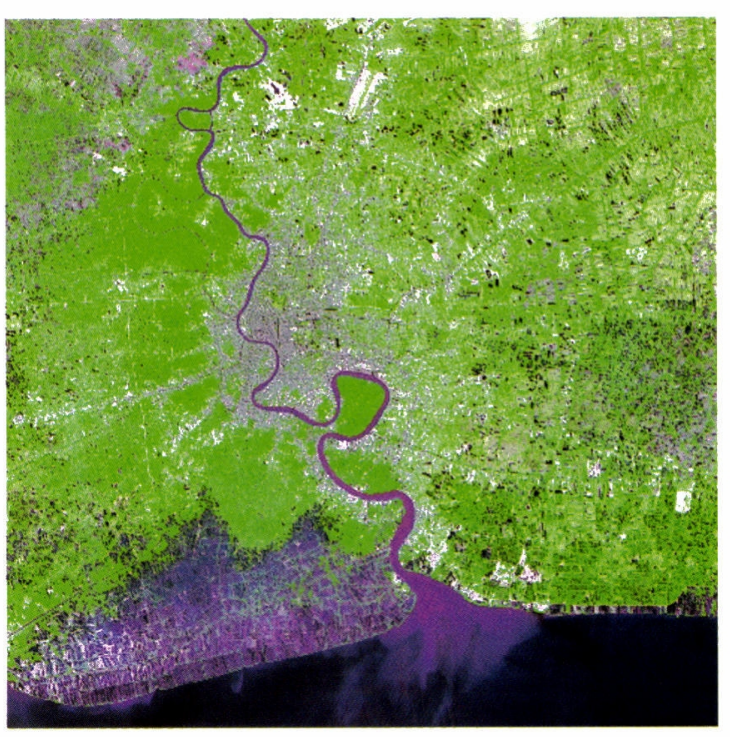

図 3 ナチュラルカラー画像

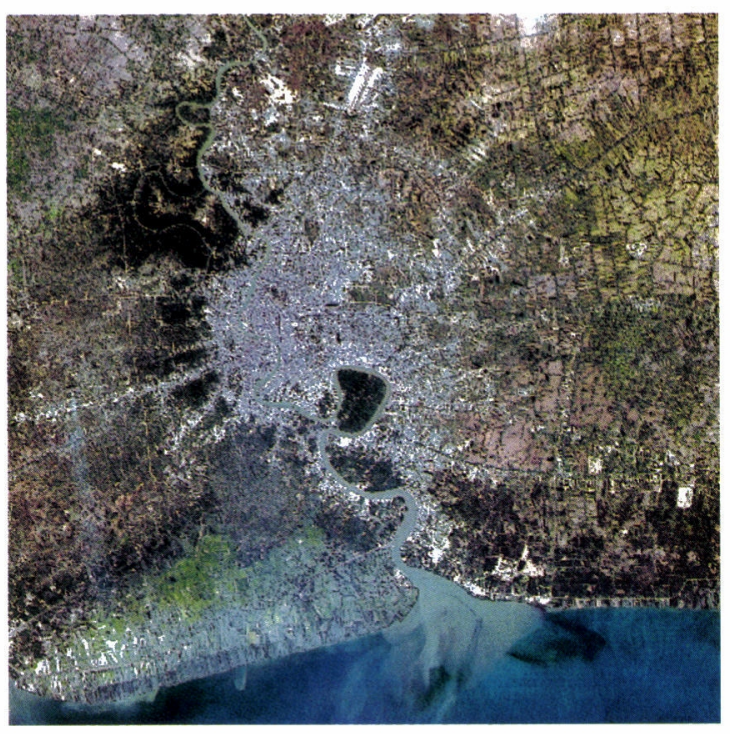

园 2 トゥルーカラー画像

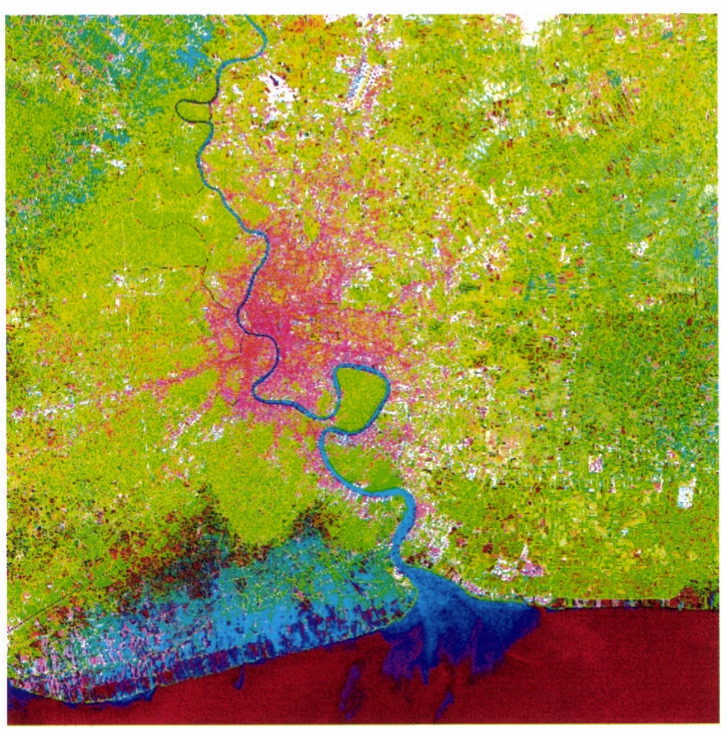

図4規準バリマックス回転画像 
考えられ，この問題を解決するために，本研究では規 準バリマックス直交回転を用いる。回転を直交変換に 限定するのは，各ピクセル間の色空間上での距離を保 持するためである。

主成分分析による第三主成分までを 3 次元情報と しここれにRGBを割り当てるとする。このとき， 3 次 元色空間上の各ピクセルの距離は求まるが，この距離 は回転に対して自由であり，色空間上での距離を変え ずに直交回転により回転させることができる。このこ とにより 3 次元情報は無相関ではなくなるが，各ピク セルの色空間上の距離を保ったまま, 各因子に意味解 釈を与えることが可能となる。

主成分分析によって, 抽出された第一から第三主成 分までに，規準バリマックス回転を適用した。回転前 後の因子負荷量を表わしたのが表 2 ( b ) である。この 因子負荷量の解釈を容易にするために, 因子負荷量が 0.7 以上， 0.5 以上のものにマークをつけた。回転の前 後を比較すると, 主成分軸の回転によって因子負荷量: は, 絶対値の大きいものは一層大きく, 小さいものは より小さくなっている。

表 2 (b)によると回転後の第一主成分 (VF1) は可 視領域のバンドと相関が高く，不可視領域のバンドと は相関が低いため，可視領域の情報を表わしていると 考之られる。同様に第二主成分は短波長赤外，第三主 成分は近郝外領域の情報をそれぞれ表わしていること がわかる。

このようにして，波長带域との関連が不明確な単な る 3 次元情報であった主成分に，主成分軸を回転する ことで波長帯域との関連という意味解釈を加えること ができ，このことを踏まえた RGBの割り当てが可能 になる。

例之ば，近赤外領域の情報を表わす第三主成分は， 植物に良く反応しているはずであり，これに緑を割り 当てれば植物の存在する地域は緑色で表現される。つ まり，第三主成分に緑を割り当てた画像を見る場合， 緑色の強いところは植物があるところだという解釈が 可能となる。また，水域は赫外線をほとんど反射しな いことから，第一主成分に青を割り当てることで水域 を青色で表示することが期待できる。以上に基づき合 成した画像が図 4 である。

この画像では地表の植物が存在すると推察されると ころが黄緑色で表され，また川をはじめ水域と予想さ れるところは青色となっている。その点に扔いて，人
間が先験的に有している土地被覆と色との対応に合致 した画像であることが確認できる。また，回転によっ ても因子軸の直交性は保持されているため, 色彩は力 ラフルであり, 図 1 の主成分分析画像と比較しても地 上物の識別可能性は高いままに保たれた。

\section{5.まとめ}

主成分分析画像はそこに含まれる物理的情報量が多 く，異なる地物を異なる色で表すという意味での識別 可能性は一般に優れる。しかし, 各主成分に波長帯域 との関連という意味がないため, 画像を構成する色と 土地被覆の対応関係が解釈しにくいものとなり，その 色彩は人間の感覚に合わない奇異なものとなる。しか し，この欠点は，主成分分析によって抽出された各主 成分に規準バリマックス回転を行うことで解決可能と なった。

規準バリマックス回転による画像を実際に合成し, 従来のフォールスカラー画像, 主成分分析画像と比較 実験を行うことで, 本手法による画像の有効性を示し た。

実験によって，主成分軸回転による画像はフォール スカラー画像よりも地上物の識別可能性に優れ，かつ 主成分分析画像では不可能であった色と土地被覆との 対応関係が解釈可能な画像であることが明らかになっ た。

特に, 水域に関してはフォールスカラー画像と比較 して, 規準バリマックス回転による画像では水域と陸 地の境界が強調され, 識別可能性の大きな向上が確認 された。これは, 赤外領域を含めた全バンドの情報を 考慮していることに起因している。この結果から, 水 域の多い画像では主成分軸回転の適用がより有効であ ることが示唆される。

なお本研究では, 主成分軸の回転によって各主成分 と波長带との関係を明確にするという点について，そ の原理の説明と実データによる検証を主たる目的とし て行った。そのため, 規準バリマックス回転画像に表 示される色と土地被覆との対応関係に関する事実確認 についてはまだ不十分な段階である。規準バリマック 又回転画像を用いた判読作業の効率性や精度が従来の フォールスカラー画像, あるいは従来の主成分分析画 像と比較してどの程度向上するかの実験，検証につい ては今後の課題である。 
(受付日1997.5.9, 受理日1997.9.12)

\section{参考文献}

1) Eklundh, L. and Singh, A.: A comparative analysis of standardised and unstandardized Principal Components Analysis in remote sensing, Int. J. Remote Sensing, Vol. 14, No.7, pp.1359-1370, 1993.

2 ) Kramber, W. J., Richardson, A. J., Nixon, P. R., and Lulla, K.: Principal component analysis of aerial video imagery, Int. J. Remote Sensing, Vol. 9, No. 9, pp.1415-1422, 1988.

3 ) Richards, J. A. : Remote Sensing Digital Image Analysis, Springer-Verlag, pp.127-147, 1986.

4) 奥野忠一, 久米 均, 芳賀敏郎, 吉澤正: 多変量 解析法 改訂版, 日科技連出版社, pp.208-219, 1981。 5 ) 杉山高一: 多変量デー夕解析入門, 朝倉書店, pp. 13-42, 1983。 